\title{
GAMBARAN KANDUNGAN BAKTERI SALMONELLA PADA AYAM BROILER YANG TERDAPAT DI CARREFOUR PENGAYOMAN KOTA MAKASSAR
}

\author{
${ }^{1}$ Nur rahmadani dan ${ }^{2}$ Inayah \\ 1,2 Jurusan Kesehatan Lingkungan Poltekkes Kemenkes Makassar \\ *) Anirahma68@gmail.com, 085299806820)
}

\begin{abstract}
Salmonella bacteria is a bacteria that trigger some diseases such as typhoid, and paratyphoid. and when Salmonella bacteria exist in the food/drinks and ingested into the body will cause symptoms such as diarrhea-diarrhea, headaches, vomiting, and fever and can end up during the 1-7 day. Chicken broiler meat is one of the potentials for the occurrence of Salmonella bacteria contamination. The goal in research is to find out if there is a content of Salmonella bacteria on the chicken broiler in Carrefour Shelter Makassar city. This type of research is observational who are descriptive. The sample in the study is taken as 6 samples, samples taken 4 in storefront and 2 samples that are frozen individually nonprobability sampling. Based on the results of the laboratory examinations on the broiler chicken meat is stored in a display case and frozen in Carrefour Shelter Makassar city Showed negative results. It is qualified based on the regulations of the head of food and drug watchdog agency of the Republic of Indonesia number Hk. 00.06.1.52,4011.Based on laboratory test results retrieved the conclusion that the existence of Salmonella on broiler chicken meat stored in a storefront and frozen showed negative results. The advice is given that is expected to manager Carrefour Shelter Makassar city to maintain the temperature of storage so that the chicken meat is not contaminated with Salmonella bacteria.
\end{abstract}

Keywords: Salmonella Bacteria, Chicken Meat Broiler

\section{ABSTRAK}

Bakteri Salmonella merupakan bakteri yang memicu sejumlah penyakit seperti tifoid, dan paratifoid. dan apabila bakteri Salmonella ada pada makanan/minuman dan tertelan masuk kedalam tubuh akan menimbulkan gejala-gejala seperti berak-berak, sakit kepala, muntah-muntah, serta demam dan dapat berakhir selama 1-7 hari. Daging ayam broiler merupakan salah satu yang berpotensi untuk terjadinya kontaminasi bakteri Salmonella. Tujuan dalam penelitian adalah untuk mengetahui apakah ada kandungan bakteri Salmonella pada daging ayam broiler yang terdapat di Carrefour Pengayoman Kota Makassar. Jenis penelitian ini adalah observasional yang bersifat deskriktif. Sampel dalam penelitian adalah diambil sebanyak 6 sampel, 4 sampel diambil dietalase dan 2 sampel yang dibekukan yang dipilih secara non probability sampling. Berdasarkan hasil pemeriksaan laboratorium pada daging ayam broiler yang disimpan dietalase dan dibekukan di Carrefour Pengayoman Kota Makassar Menunjukkan hasil negatif. Hal ini memenuhi syarat berdasarkan peraturan kepala badan pengawas obat dan makanan Republik Indonesia nomor Hk.00.06.1.52,4011. Berdasarkan hasil uji laboratorium diperoleh kesimpulan bahwa kebaradaan Salmonella pada daging ayam broiler yang disimpan dietalase dan dibekukan menunjukkan hasil negatif. Saran yang diberikan yaitu diharapkan kepada pihak pengelolah Carrefour Pengayoman Kota Makassar agar mempertahankan suhu penyimpanan supaya daging ayam tidak terkontaminasi dengan bakteri Salmonella.

Kata Kunci : Bakteri Salmonella, Daging Ayam Broiler

\section{PENDAHULUAN}

Makanan adalah kebutuhan

pokokmanusia yang dibutuhkan setiap saat dan memerlukan pengolahan yang baik dan benar agar bermanfaat bagi tubuh. Menurut WHO (World Health Organization), yang dimaksud makanan adalah "Food include all substance, whether in a natural state or in a manufactured or preparedfrom, wich are part of human diet." Batasan makanan tersebut tidak termasuk air, obat-obatan dan substansi-substansi yang diperlukan untuk tujuan pengobatan. karena pentingnya makanan bagi tubuh kita maka hendaknya perlu untuk menjaga hygiene dan sanitasi makanan tersebut agar dapat kita komsumsi secara sehat dan tidak menimbulkan penyakit bagi tubuh kita (Nurul, 2017).

Berbagai tipe keracunan makanan (food poisoning, foodborne illens, foodborne disease) dilaporkan dari seluruh penjuru dunia toksin yang menyebabkan keracunan daging ayam di hasilkan oleh berbagai spesies bakteri yang dalam kondisi cahaya, suhu, dan pasokan nutrisi tertentu sebagai penunjang pertumbuhan bakteri pada ayam seperti bakteri salmonella. Makanan merupakan kebutuhan pokok manusia karena didalamnya mengandung nutrisi yang diperlukan antara lain untuk pertumbuhan badan, memelihara jaringan tubuh yang rusak, berkembang biak, dan mengasilkan energi untuk dapat melakukan aktivitas. Makanan yang kita makan bukan saja harus memenuhi nilai gizi dan mempunyai bentuk yang menarik, akan tetapi harus aman dalam arti tidak mengandung mikroorganisme dan bahan-bahan kimia dapat menyebabkan penyakit. Potensi bahaya pada makanan bisa bersumber dari faktor biologi, kimia, maupun fisik. Bakteri merupakan penyebab kasus keracunan makanan terbesar. Dikenal dua tipe keracunan makanan, yaitu infeksi dan intoksikasi (Rusdin, 2013) 
Jurnal Sulolipu : Media Komunikasi Sivitas Akademika dan Masyarakat

Vol. 19 No.2 2019

e-issn : 2622-6960, p-issn : 0854-624X

Makanan yang dikomsumsi hendaknya memenuhi kriteria bahwa makanan tersebut layak untuk dimakan dan tidak menibulkan penyakit, diantaranya berada dalam derajat kematangan yang dikehendaki, bebas dari pencemaran di setiap tahap produksi dan penanganan selanjutnya, bebas dari perubahan fisik, kimia yang tidak di kehendaki, sebagai akibat dari pengaruh enzim, aktifitas mikroba, hewan pengerat, serangga, parasit dan kerusakan-kerusakan karena tekanan, pemasakan, pengeringan, dan bebas dari mikroorganisme dan parasit yang menimbulkan penyakit yang di hantarkan oleh makanan.

Adanya bakteri salmonella di darat dapat berasal darii kontaminasi beberapa sumber pencemar yaitu kotoran hewan pada saat di potong, kotoran manusia, alat/mesin yang di gunakan pada saat pemotongan atau air yang terkena polusi buangan yang mengandung salmonella. $\mathrm{Di}$ dalam kehidupan bakteri salmonella sangat dipengaruhi faktor lingkungan dan nutrisi, ayam merupakan tempat yang bagus bagi perkembangan bakteri salmonella karena daging ayam memiliki protein dan nutrisi yang tinggi yang disukai oleh salmonella para ahli gizi juga menyatakan bahwa ayam merupakan makanan yang bernutrisi tinggi (K.A. Buckle.dkk 1985).

\section{Bahan dan alat}

Populasi dalam penelitian ini adalah Yang menjadi populasi dalam penelitian ini adalah seluruh daging ayam broiler yang dijual di Carrefour Pengayoman Kota Makassar, dimana ayam broiler yang di simpan dietalase terdapat 50 ayam dan ayam broiler yang dibekukan terdapat 30 ayam broiler

Bahan yang digunakan dalam penelitian ini adalah Sampel makanan. Endo agar. Triple sugar iron agar (TSIA). Kligler iron agar (KIA). Media gula-gula (Maltosa, Manit, Sakarosa, Laktosa, Glukosa). Aquades

Alat yang digunakam dalam penelitian ini adalah Tabung reaksi. Gelas ukur. Pipet ukur $10 \mathrm{ml}$. Petridish beaker gelas. Tabung durham. Incubator. Autoclave. Lampu spritus. Balp. Ose

\section{Langkah-langkah Penelitian}

Ambil sampel makanan yang representative (Terwakili). Masukkan ke dalam wadah plastik steril hancurkan. Kemudian di tambahkan Aquadest secukupnya hingga sampel tecampur homogeny. Ambil sampel 1 s/d 2 mata ose, goreskan 4 kuadran pada petridish steril yang terisi endo agar steril yang telah dibekukan. Eramkan selama 18-24 jam dengan suhu $37^{\circ} \mathrm{C}$. Amati, jika koloni berwarna merah rose (merah muda), coloni kecil dan berwarna putih berarti dicurigai positif. Tanam pada media TSIA 1-2 mata ose secara zig-zag pada lereng dan tusuk hingga kedasar

.Eramkan selama $18-24$ jam dengan suhu $37^{\circ} \mathrm{C}$. Dinyatakan positif jika lereng berwarna merah, dasar kuning dan pada tusuk tidak hitam. Lanjutkan pada media gula-gula dan KIA 102 mata ose. Eramkan dengan suhu $37^{\circ} \mathrm{C}$ selama 18-24 jam. Bacalah dalam tabel untuk menentukan jenis salmonella. pada KIA apabila tusuk pertama ada warna hitam maka menandakan adanya gas H2S dan pada lereng warna merah dengan dasar kuning

\section{Pengolahan Data}

Data yang diperoleh dari hasil observasi di lapangan dan hasil uji laboratorium dalam penelitian ini diolah dengan cara komputerisasi menggunakan Microsoft word dan Microsoft excel.

HASIL

Tabel 1

Gambaran Kandungan Bakteri Salmonella pada Ayam Broiler yang Dibekukan Terdapat di Carrefour Pengayoman Kota Makassar, 29 April 2019 :

\begin{tabular}{cccc}
\hline No & $\begin{array}{c}\text { Nama } \\
\text { Sampel }\end{array}$ & Salmonella & Keterangan \\
\hline 1 & $\begin{array}{l}\text { Ayam } \\
\text { beku }\end{array}$ & $(-)$ & Negatif/25 gr \\
2 & $\begin{array}{l}\text { Ayam } \\
\text { beku }\end{array}$ & $(-)$ & Negatif/25 gr \\
\hline
\end{tabular}


Jurnal Sulolipu : Media Komunikasi Sivitas Akademika dan Masyarakat

Vol. 19 No.2 2019

e-issn : 2622-6960, p-issn : 0854-624X

Tabel 2

GambaranKandunganBakteriSalmonella pada Ayam Broiler Yang DietalaseTerdapat di Carrefour PengayomanKota Makassar, 29 April 2019:

\begin{tabular}{cccc}
\hline No & Nama Sampel & Salmonella & Keterangan \\
\hline 1 & Ayam Etalase & $(-)$ & Negatif/25 gr \\
2 & Ayam Etalase & $(-)$ & Negatif $/ 25 \mathrm{gr}$ \\
3 & Ayam Etalase & $(-)$ & Negatif $/ 25 \mathrm{gr}$ \\
4 & Ayam Etalase & $(-)$ & Negatif/25 gr \\
\hline
\end{tabular}

Hasil diatas pada tabel 4.1 dan tabel 4.2 dapat dilihat bahwa sampel makanan (daging ayam broiler) yang terdapat di Carrefour Pengayoman Kota Makassar negatif mengandung bakteri Salmonella berdasarakan badan POM, No:HK.00.06.1.52.401/2009 tentang jenis dan batas maksimum cemaran mikroba dalam makanan, jika hasil pemeriksaan bakteri Salmonella negatif/25 gram. Daging ayam broiler yang terdapat di Carrefour pengayoman kota makassar, pangambilan sampel yaitu 2 titik di etalase dan dibekukan di mana di etalase di ambil 4 sampel dan dibekukan di ambil 2 sampel di Carrefour Pengayoman Kota Makassar diperoleh hasil pemeriksaan kandungan Salmonella negatif (-) 25/gram.

\section{PEMBAHASAN}

Penelitian ini dilakukan karena bakteri Salmonella merupakan bakteri yang memicu sejumlah penyakit seperti food borne disiase, tifoid, dan paratifoid. Apabila bakteri Salmonella ada pada makanan/minuman dan tertelan masuk kedalam tubuh akan menimbulkan gejala-gejala seperti berak-berak, sakit kepala, muntah-muntah, serta demam dan dapat berakhir selama 1-7 hari. Dan jika Salmonella semakin tinggi dalam suatu makanan, maka semakin cepat waktu inkubasi sampai gejala infeksi (Rusdin Rauf,2013). Jenis-jenis bakteri Salmonella ini mampu bergerak leluasa kemudian menghasilkan hydrogen sulfide yang beracun terhadap manusia jika dikonsumsi dalam jumlah yang banyak. Salmonella dapat ditemukan di tanah, air, makanan mentah, dan kotoran beberapa hewan. Bakteri Salmonella ini dapat masuk ke dalam tubuh manusia melalui komsumsi makanan yang tercemar. bakteri Salmonella. salah satu makanan yang dapat mengandung bakteri Salmonella yaitu daging ayam broiler, jika keamanannya diduga telah terkontaminasi kandungan bakteri Salmonella. Hal ini disebabkan karena air yang digunakan pada saat pencucian dan alat yang digunakan pada saat pemotongan terkontaminasi, walaupun demikian hasil pengamatan yang dilakukan oleh stteiniger (dalam grunnet 1975) menunjukan bahwa bakteri Salmonella paratyphi B masih dapat hidup di darat yang mengandung kadar protein tinggi. Pada umumnya bakteri Salmonella penyebarannya di pengaruhi oleh faktor fisik. selain faktor fisik juga nutrisi dan kondisi lingkungan yang sesuai sangat mendukung kehidupannya untuk berkembang biak.

Penelitian ini dilakukan untuk mengetahui ada atau tidaknya kandungan bakteri Salmonella pada daging ayam broiler yang terdapat di Carrefour Pengayoman Kota Makassar. Pemeriksaankandungan bakteri Salmonella pada ayam broiler, pada penelitian ini adalah observasional melalui pemeriksaan di laboratorium yaitu untuk mengetahui cemaran bakteri Salmonella pada ayam broiler yang terdapat di Carrefour Pengayoman Kota Makassar.

Berdasarkan hasil dari pemeriksaan kandungan bakteri Salmonella yang diperiksa pada daging ayam broiler, koloni tidak ditemukan Salmonella pada medium agar menunjukkan bahwa semua sampel yang diperiksa tidak tercemar bakteri Salmonella, yang berarti bahwa rangkaian proses pemotongan ayam broiler dan alat yang digunakan tidak terkontaminasi. Kemungkinan tidak adanya kandungan bakteri Salmonella pada ayam broiler karena dipengaruhi oleh suhu dan tempat penyimpanan.

Rendahnya tingkat pencemaran yang memungkinkan perkembangan bakteri Salmonella tidak pesat karena dipengaruhi oleh tempat penyimpanan, dimana pada penyimpanan ayam yang di simpan dietalase dan dibekukan tidak banyak kontaminasi oleh tangan manusia karena ayam dikemas dengan plastik sehingga faktor untuk pertumbuhan bakteri dihambat dengan pesat, di bandingkan dengan ayam yang dijual di pasar tempat penyimpanan terbuka sehingga mudah terkontaminasi oleh bakteri. Bakteri sangat tergantung oleh factor lingkungan, suhu dan nutrisi. Telah diketahui suhu optimum yang mendukung pertumbuhan bakteri Salmonella adalah $30-37^{\circ}$ sehingga tidak ditemukannya 
Jurnal Sulolipu : Media Komunikasi Sivitas Akademika dan Masyarakat

Vol. 19 No.2 2019

e-issn : 2622-6960, p-issn : 0854-624X

bakteri Salmonella pada ayam yang telah diperiksa.

Hasil pemeriksaan yang telah dilakukan diperoleh hasil negatif pada daging ayam broiler pada semua titilk pengambilan sampel baik dietalase maupun yang dibekukan di Carrefour Pengayoman Kota Makassar. Hasil ini sesuai standar persyaratan menurut peraturan Badan Pengawas Obat dan Makanan tahun 2009 yaitu negatif.

Kandungan bakteri Salmonella didarat (ayam broiler) dipengaruhi oleh beberapa faktor fisik diantaranya seperti alat pada saat pemotongan dan air yang digunakan pada saat pencucian. Selain faktor fisik juga nutrisi dan kondisi lingkungan yang sangat mendukung kehidupannya untuk berkembang biak. Bakteri Salmonella ini bakteri asal darat atau air tawar yang penyebarannya melalui berbagai cara berdasarkan habitatnya ( K.A Buckle dkk,1985).

Hasil pemeriksaan yang telah dilakukan maka daging ayam broiler yang terdapat di Carrefour Pengayoman Kota Makassar aman atau layak dikonsumsi oleh masyarakat.

Daging ayam broiler adalah hewan yang termasuk hewan bertubuh lunak (moluska) yang memiliki bulu. Jenis ayam broiler juga menyediakan kalium sebanyak 10 persen dari jumlah asupan yang disarankan untuk setiap 100 gramnya. Ayam ternyata mengandung vitamin $E$, juga merupakan sumber vitamin $B$ kompleks yang baik. Meskipun ayam mengandung kolestrol yang cukup tinggi namun kadar lemak total dan lemak jenuhnya rendah . bahkan ayam memiliki kandungan lemak jenuh tak ganda yang tinggi, dapat menimbulkan penumpukan kolesterol dan melekatnya bintikbintik darah pada dinding pembuluh darah yang merupakan sebab utama serangan jantung dan stroke yang mematikan. 
Jurnal Sulolipu : Media Komunikasi Sivitas Akademika dan Masyarakat

Vol. 19 No.2 2019

e-issn : 2622-6960, p-issn : 0854-624X

\section{DAFTAR PUSTAKA}

Andjar Prasetyo, 2017. Analisis Olahan Pangan. Jakarta : Indicomp

Arisman, 2009, Buku Ajar IImu Gizi. Keracunan Makanan Jakarta : EGC

Badan Standarlisasi Nasional. 2008. Mutu Karkas dan Daging Ayam. (Sni 3924:2009).Jakarta. Badan Standar Nasional. (https:/Www.Academia.Edu di akses 25 Desember 2018)

Direrktorat Jenderal Perternakan dan Kesehatan Hewan. 2010. Pedoman Produksi Dan Penangan Daging Ayam Yang Higienis. Departemen Litban,Jakarta. (online). (Http://Setkab.go.id di akses 30 Desember 2018).

Fardiaz, S.,S.1981. Masalah Keamanan Pangan Dalam Hubungannya Dengan Mikrobiologi Veterineri. Kumpulan Makalah Kongres Nasional Mikrobiologi Ke lii Jakarta, 26-28 November 1981 :307310.(http://Jurnal.Fk.Unand.ac.id di akses 25 Desember 2018)

Hasrawati, 2017. Tingkat Cemaran Bakteri Salmonella Sp Pada Daging Ayam Yang Dijual di Pasar Tradisional Makassar. Jurusan IImu Perternakan Fakultas Sains dan Teknologi Universitas Islam Negeri Alauddin Makassar (Skripsi Tidak Dipublikasikan)

Imam Rahayu Dkk, 2011. Panduan Lengkap Ayam. Jakarta : Swadaya

Inayah, Zaenab.2017. Buku Panduan Praktikum Penyehatan Makanan dan Minuman. Makassar : Politeknik Kesehatan Makassar Jurusan Kesehatan Lingkungan

K.A. Buckle Dkk.1985. Ilmu Pangan. (ab Hari Purnomo dan Adiono) Jakarta: Universitas Indonesia (UIPress)

Kiki Risky Amelia.2015. Analisa Kandungan Salmonella Pada Kerang Tiram di Muara Sungai Lajari Kab. Barru. Makassar: Politeknik Kesehatan Jurusan Kesehatan Lingkungan Makassar (KTI Tidak Dipublikasikan) 